\title{
THE POSSIBLE MACROPHAGE ROLE IN SEMINAL FLUID
}

\author{
E.A. SOLIS*, B.R. BOUVET*, A.S. BRUFMAN*, R. FELDMAN**, \\ V. N. GATTI* \\ *Dept. of Clinical Biochemistry. University of Biochemistry and Pharmaceutical Sciences. Rosario (Argentina). \\ Reproduction Service. Eva Peron School Hospital. National University of Rosario (Argentina). \\ **Reproduction Service. Faculty of Medical Sciences. National University of Rosario (Argentina).
}

Actas Urol Esp. 27 (3): 185-189, 2003

\section{RESUMEN}

"POSIBLE ROL DE LOS MACRÓFAGOS EN FLUIDO SEMINAL"

Este trabajo se realizó para estudiar el rol de los macrófagos en semen y su asociación con: el porcentaje de espermatozoides con DNA nativo, morfología espermática y presencia de anticuerpos antiespermáticos (AAE).

Se utilizó muestras de semen de 31 pacientes y se evaluaron según los criterios de la Organización Mundial de la Salud. La cromatina nuclear se estudió con Naranja de Acridina, fluorocromo que discrimina el DNA nativo, color verde, del DNA desnaturalizado, color anaranjado. La concentración de macrófagos se determinó utilizando Rojo Neutro para teñir las células fagocíticas y cámara de Neubauer para contar. La presencia de AAE se investigó mediante reacción de aglutinación mixta.

Se encontró asociación entre la presencia de AAE y concentración de macrófagos $(\mathrm{p}<0,05)$. Hubo correlación significativa entre presencia de macrófagos y espermatozoides con DNA desnaturalizado $(\mathrm{p}<0,05)$. Pero no hubo asociación significativa entre concentración de macrófagos y morfología espermática (p:0,414). Concluimos que existe un fuerte indicio de que los macrófagos presentes en plasma seminal participan en el mecanismo fagocítico contribuyendo a la calidad seminal, facilitando la fertilización.

PALABRAS CLAVE: Concentración de macrófagos. Anticuerpos antiespermáticos. Inmunovigilancia. DNA espermático. Morfología espermática. Infertilidad masculina.

\section{ABSTRACT}

"THE POSSIBLE MACROPHAGE ROLE IN SEMINAL FLUID"

The present report was designed to study the macrophage role and their association with percentage of spermatozoa showing DNA native, morphologically normal sperm and occurrence of antibody-coated spermatozoa.

Human sperm samples from 31 patients were used in this study. All samples were evaluated for standard semen parameters according to World Health Organization criteria. The sperm heads with abnormal versus normal chromatin structure were specified as orange-red versus green by Acridine Orange method. Macrophage concentration was assessed with Neutral Red in Neubauer hemocytometer. The technique for the determination of sperm bound antisperm antibodies was sperm mixed antiglobulin reaction. In our study the presence of antisperm antibodies in associated to macrophages concentration $(p<0.05)$. The $\log$ of phagocytic cells were highly correlated with an increase of spermatozoa showing DNA denaturation $(\mathrm{p}<0.05)$. The log of phagocytic cells were highly correlated with an increase of spermatozoa showing DNA denaturation $(\mathrm{p}<0.05)$. There isn't significative association between the log macrophage concentration and morphologically normal sperm (p:0.414).

Thus, the present study further emphasizes the importance of immunosurveillance of the macrophages, and the contribution at the semen quality for the success of the fertilization.

KEY WORDS: Macrophages concentration. Antisperm antibodies. Immunosurveillance. Sperm DNA. Sperm morphology. Infertility male. 
$\mathrm{D}$ espite advances in understanding reproduction human physiology, $10 \%$ to $15 \%$ of infertile couples have no identifiable cause of their infertility. Numerous studies have postulated the key factors responsible for the prediction of man potential fertility including spermatic count, acrosoma state, integrity of the cell membrane, morphology and morphometry of the whole spermatozoa and/or of the head and integrity of nuclear chromatin. Therefore, an only one laboratory test cannot predict the entire human fertility.

With regard the morphology in the W.H.O. last manual ${ }^{1}$ there is recognition of the fact that there is still no agreement about the cutoff to be adopted for a "normal morphology criterium" and it has been suggested that less than $15 \%$ of normal shapes, reduce the possibility of in vitro fertilization. Moreover, the human sperm are characterized by great heterogeneity in their morphology, motility and nuclear integrity and maturity, which makes it more difficult to predict semen quality. Sperm morphology, especially the occurrence of increased head defects, is an indicator of poor fertilizing potential. Reports by Evenson et al., suggest that abnormal-shaped sperm nuclei have an altered chromatin structure that would be reflected in an abnormal DNA denaturation profile. One of the methods used to study chromatin integrity is staining of the spermatozoa with acridine orange. Sperm cells having DNA that is sensitive to denaturation also have DNA strand breaks. Acridine orange stain's green with normal double-stranded DNA and orange-red with single-stranded DNA. Increased red fluorescence indicates increased sensitivity to denaturation ${ }^{2}$.

As tested by the in situ DNA denaturation test with acridine orange (AO), it was shown that DNA is more prone to denaturation by heat or low $\mathrm{pH}$ in human sperm nuclei with abnormal chromatin structure than in nuclei with normal chromatin.

It is well known that between $8 \%$ and $15 \%$ of the male members of infertile couples have antibodies which may play an important role in the problem. Isoantibodies, generated by women in response to the spermatic antigenic stimulus are fundamentally produced in the cervix. The autoantibodies are produced by the male immune system against antigens developed at spermatic level in the postpubertal period and are not recognized by the immune system because they had not been developed at the time of the recognition of what is one's own and what is not. This fact is facilitated by all those pathological processes in which there is an interruption in the haematotesticular barrier. There are various mechanisms through which Antisperm Antibody (ASA) can interfere with the reproductive process. Once joined to the spermatozoa, the ASA might damage functions in one and/or various ways: a) interference with sperm motility and penetration of cervical mucus. b) lysis of antibody-coated sperm by complement. c) interference with sperm capacitation. d) blocking of sperm-oocyte interaction. e) leukocyte phagocytosis of antibody-opsonized.

Three types of seminal phagocytic cells were found: small polymorphonuclear leukocytes $(10 \approx 12 \mu \mathrm{m})$ monocytes of similar size, and much larger $(30-40 \mu \mathrm{m})$ macrophages capable of engulfing multiple sperm heads. The clear discrepancy between the number of spermatozoa produced by testis and those ejaculated is indicative of sperm resorption and/or phagocytic clearance mechanism. A very important chapter in Immunology ponders physiological resources for the elimination of senescent and/or abnormall cells. This is made manifest in Tomlinson's work (1992). Barrat and Cohen attribute the role of "carrion" cells to macrophages because they are capable of removing the morphologycally abnormal sperm. Another cause that may expose spermatozoa to macrophage action is the presence of antibodies ${ }^{3-5}$.

\section{OBJ ECTIVE}

The present report was designed to study the macrophage role and their association with of spermatozoa showing DNA native, morphologically normal sperm and occurrence of antibodycoated spermatozoa.

\section{MATERIAL AND METHODS}

Human sperm samples from 31 patients were used in this study. Semen samples were collected from an unselect group of men attending the Reproduction Service of the School Hospital of University National Rosario (República Argentina) for the investigation of men infertility. In all cases, after 3-5 days of sexual abstinence, samples were collected by masturbation into wide-mouthed ste- 
rile containers and were derivered to the laboratory within 1 hour of ejaculation. All samples were evaluated for standard semen parameters according to W.H.O. criteria ${ }^{1}$.

Neutral Red Tinction:

Reagent: A $0.01 \%$ solution of Neutral Red (Colour Index-C.I. 50040 Sigma) in $9 \mathrm{~g} / 1$ aqueous sodium chloride solution.

Procedure: $50 \mu \mathrm{l}$ of fresh semen samples were mixed with $50 \mu \mathrm{l}$ of Neutral Red solution in a closed Eppendorf tube at $37^{\circ} \mathrm{C}$ for about 5 minutes. The stained cells (activate macrophages) with Neutral Red were count in Neubauer hemocytometer. As a general guide, a normal ejaculate should not contain more than $0.6 \times 10^{6}$ activate macrophages $/ \mathrm{ml}^{6}$.

Acridine Orange staining (modified method):

Reagent: Acridine Orange (C.I. 46005 Sigma) 1 $\mathrm{g}$ in $100 \mathrm{ml}$ to phosphate buffered saline (PBS).

Procedure: In brief, the fresh semen samples were mixed with Acridine Orange solution on a microscope slide with a cover slip and examine after 2 minutes at 400x with a fluorescence microscope. Sperm cells heads with good DNA integrity had green fluorescence and those with diminished DNA integrity had orange-red staining?.

Acridine orange staining showed $>50 \%$ green fluorescence in samples obtained from a fertile donors and this was taken as the cutt off value.

Sperm morphology:

For the assessement of sperm morphology, $20 \mu \mathrm{l}$ of fresh semen after liquefaction were used, and placed on a glass microscope slide and the drop is spread across the slide. These slide are allowed to dry in air and then fixed in methanol/ether (1:1) at least for 30 minutes. Sperm morphology was assessed on a Papanicolaou stained semen smear and read using bright field ilumination (x1000). The number of abnormalities in 100 spermatozoa was evaluated, and normal morphology using the guidelines promulgated by the WHO 1999. Data of assisted reproductive technology programmes suggest that, as sperm morphology falls bellow $15 \%$ normal forms the fertilization rate in vitro decreases

Sperm autoimmunity: Direct sperm mixed antiglobulin reaction test were perfomed by placing on a microscope slide $10 \mu \mathrm{l}$ semen, $10 \mu \mathrm{lg}$ G coated red blood cells suspension and $10 \mu \mathrm{rab}-$ bit antihuman Ig G Fc antiserum. The semen and red blood cells suspension were mixed with antiserum, and the mixture was examined microscopically and evaluated for the percentage of red blood cells binding after 3 and 10 minutes. Consistent with the specifications of the manufacture, immunological infertility was considered probable if greater than $25 \%$ spermatozoa were bound to the red blood cells ${ }^{8}$.

Statistical Analysis:

The joint distribution of the three quantitative variables (percentage of morphologically normal sperm, percentage of sperm with native DNA and macrophages concentration) by means of Mardia's Test, null hypothesis being rejected. The log (macrophage concentration) was used.

Partial correlation coeficients were calculated. These values and their corresponding $\mathrm{p}$. values are reported (Table I).

TABLE I

PARTIAL CORRELATION COEFICIENTS

\begin{tabular}{|l|c|c|}
\hline Variables & $\mathrm{r}$ & $\mathrm{p}$-value \\
\hline $\begin{array}{l}\text { Log Macr.conc. \% of morph } \\
\text { normal sperm }\end{array}$ & -0.04 & 0.414 \\
\hline $\begin{array}{l}\text { Log Macr.conc. \% of sperm } \\
\text { with denatured DNA }\end{array}$ & -0.21 & 0.110 \\
\hline
\end{tabular}

Therefore, the conclusion is that there exists a lightly significant association between the variables log macrophage concentration and percentage of sperm with denatured DNA $(\mathrm{p}<0.05)$.

When categorizing the three variables according to the values obtained whether they belong to the reference range or not and after applying either the Chi-Square Tet or the Fisher Exact Test depending on which of both has to be applied. The conclusion is that there is a significant association between the macrophage concentration and the spermatozoa with denatured DNA $(\mathrm{p}<0.05)$ (Table II), not so with morphologically normal sperm (Table III).

The presence of antispermatic antibodies is associated to macrophage concentration $(\mathrm{p}<0.05)$ (Table IV). The proportion of negative antispermatic antibodies is significatilly lower in patients with normal macrophage concentration than in those with abnormal concentration. 


\section{TABLE II}

MACROPHAGE CONCENTRATION VERSUS SPERMATOZOA WITH DENATURED DNA PERCENTAGE

\begin{tabular}{||l|c|l|}
\hline \multicolumn{3}{|c|}{ Chi-Square Test } \\
\hline Chi-Square & Df & p-value \\
\hline 5.55 & 1 & 0.0185 \\
\hline 3.95 & 1 & 0.0469 with Yates' correction \\
\hline
\end{tabular}

Fisher's Exact Test for 2 by 2 tables

One-tailed $\mathrm{p}$-value $=0.0225726$

Two-tailed $\mathrm{p}$-value $=0.0290081$

\section{TABLE III}

MACROPHAGE CONCENTRATION VERSUS MORPHLOGICALLY NORMAL SPERM PERCENTAGE

\begin{tabular}{||l|c|l||}
\hline \multicolumn{3}{|c|}{ Chi-Square Test } \\
\hline Chi-Square & Df & p-value \\
\hline 0,58 & 1 & 0.4466 \\
\hline 0,12 & 1 & 0.7340 with Yates' correction \\
\hline
\end{tabular}

Fisher's Exact Test for 2 by 2 tables

One-tailed p-value $=0.362494$

Two-tailed p-value $=0.675719$

\section{TABLE IV}

MACROPHAGE CONCENTRATION VERSUS ANTIESPERMATIC ANTIBODIES OCCURRENCE

\begin{tabular}{|l|c|l|}
\hline \multicolumn{3}{|c|}{ Chi-Square Test } \\
\hline Chi-Square & Df & p-value \\
\hline 4,92 & 1 & 0.0266 \\
\hline 3,40 & 1 & 0.0652 with Yates' correction \\
\hline
\end{tabular}

Fisher's Exact Test for 2 by 2 tables

One-tailed p-value $=0.0323612$

Two-tailed $\mathrm{p}$-value $=0.0596103$

\section{DISCUSSION}

The possibility that macrophages may play a positive role in the control of semen quality was suggested by the interesting studies of Tomlinson (1992). Specifically, the authors postulated that phagocytes might shape the quality of the human ejaculate by phagocytosing morphologically abnormal spermatozoa.

We conclude that there isn't significative association between the log. Macrophage concentration and morphologically normal sperm (p: 0.414).
Interestingly, there appear to be notably more macrophages in the semen of men with anti-sperm antibodies although the cause of this is unknow. An increase in the phagocytic activity of the leucocytes in men with antiesperm antibodies may expected as many of the spermatozoa would be opsonized by antibody. Previous studies have indicated an increase in phagocytosis of antibody-coated spermatozoa by peripheral blood leucocytes. In our study the presence of antisperm antibodies is associated to macrophages concentration $(\mathrm{p}<0.05)$.

The integrity of the nucleus of human spermatozoa is essential to achieve fertilization and embryo development. The nuclear chromatin undergoes a series of changes: chromatin condensation, stabilization timely decondensation, replacement of nucleoprotamines by histones and DNA synthesis, during its journery from the testis to the site of fertilization in the female. Disorders of chromatin structure can cause unexplained infertility or lower fertilization potential that may go undetected in routine analysis of semen. Along with the macrophages, these phagocytic cells were highly correlated for another author with an increased percentage of morphologically ideal sperm, in agreement with our earlier findings suggesting that in certain individuals both neutrophils and to a lesser extent macrophages may "cleanse" and increase the quality of an ejaculate possibly by removal of abnormal and degenerate forms. The log of phagocytic cells were highly correlated with an increased of spermatozoa showing DNA denaturation $(\mathrm{p}<0.05)$.

Thus, the present study further emphasizes the importance of immunosurveillance of the macrophages, and the contribution at the semen quality for the succes of the fertilization.

This intense leucocyte reaction is a physiological response specifically to spermatozoa and may serve as a for of immunological filter, whose function is to recognize and select the sperm population wich will make the find stage of the journey to the site of fertilization.

Acknowledgements. The autors wish to acknowledge Statistical Mercedes Leiva and Biochemistry Hebe Bottai for their statistical work. We also thank Teacher Aurelia Vincent for translation to English. 


\section{REFERENCES}

1. WORLD HEALTH ORGANIZATION.: WHO laboratory manual for the examination of human semen and sperm cervical-mucus interaction. Cambridge University Press. Cambridge 1999.

2. GOPALKRISHNAN K, HURKADLI K, PADWAL V, BALAJAH D.: Use of acridine orange to evaluate chromatin integrity of human spermatozoa in different groups of infertile men. Andrología 1999; 31: 277-282.

3. TOMLINSON MJ, WHITE A, BARRATT CLR, BOLTON AE, COOKE ID.: The removal of morphologically abnormal sperm forms by phagocytes: a positive role for seminal leukocytes? Human Reproduction 1992; 7 (4): 517-522.

4. BARRAT CLR, BOLTON AE, COOKE ID.: Functional significance of white blood cells in the male and female reproductive tract. Human Reproduction 1990; 5 (6): 639-648.

5. LONDON SN, HANEY AF, WEINBERG BJ.: Macrophages and infertility: enhancement of human macrophage mediated sperm killing by antisperm antibodies. Fertility and Sterility 1985; 43 (2): 274 -278.
6. BOUVET B, BRUFMAN A, GATTI V, SOLIS E, FELDMAN R, PROVENZAL O.: Cellular sub-population in semen. Biocell 2000; 24 (2): 164 (Abstract).

7. TEJADA RI, MITCHELL JC, NORMAN A, MARIK JJ, FRIEDMAN S.: A test for the practical evaluation of male fertility by acridine orange (AO) fluorescence. Fertility and Sterility 1984; 42: 87-91.

8. GATTI V, SOLIS E, BRUFMAN A et al.: Comparative results of two sperm antibody assay in infertile patients. Validation of a new technique. Acta Urológica Itálica 1998; 12 (6): 321-323.

Dra. E. Amalia Solis

Martín Fierro 218

2000 - Rosario (Sta. Fe)

República Argentina

(Trabajo recibido el 18 junio de 2002) 